INTERNATIONAL JOURNAL OF MULTIDisciplinARY RESEARCH AND ANALYSis

ISSN (print): 2643-9840, ISSN (online): 2643-9875

Volume 04 Issue 05 May 2021

DOI: 10.47191/ijmra/v4-i5-28, Impact Factor: 6.072

Page No. $-674-675$

\title{
Sogdian Epitaphs in Honor Early Khagans of Tyurkik Khaganat
}

\author{
Professor M.M. Iskhakov
}

Tashkent State University of Oriental Studies, Uzbekistan

ABSTRACT: This scientific report devoted to interpretation the content of too sogdian memorial epitaphs in honor early rulers of Turkik Khaganate.

KEYWORDS: Bugut, Kagan, Khaganat, Sogdian script, Bumin, Taspar, Nivar, Yoshida, Bagi, ruler, Chinese sources.

\section{INTRODUCTION}

In the context of the intensive development of the Great Silk Road under the supervision of the Turkic Khaganate in the early Middle Ages and the active participation of Sogdian merchants in international trade and cultural relations along its routes, there was a tradition of active use of the Sogdian script, which is more convenient and easy for the process of recording business and other acts. Along with the ancient Turkic alphabet, which had a monumental character, the Sogdian script was also used in the compilation of commemorative inscriptions on tombstone steles in honor of the khagans and their close associates of the last quarter of the VI century AD. Although in one of his works, the famous scientist-Iranist V. B. Henning noted the unsuitability of the Sogdian cursive for monumental purposes on solid material, in particular on stone, nevertheless, it was used more than once to perpetuate the memory of the first persons of the Khaganate.

\section{THE MAIN RESULTS AND FINDINGS}

For example, one stele with a Sogdian inscription is now widely known in Sogdian studies as the Bugut stele, which was found in 1956 by the Mongolian archaeologists J. R. R. Tolkien fnd Dorzh Suren in the Bugut locality of the Archangay region of the Mongolian People's Republic and published by S. G. Klyashtorny and V.A. Livshits. The second inscription, carved on a stone statue in memory of Niri Kagan, who died in 599, was found in the steppe of Mongol-Kure near the Tekes River, in Zhaosu County, in the Xinjiang Uyghur Autonomous Region of the People's Republic of China. This text was first discovered by Chinese archaeologists in 1953, but has been interpreted by many researchers as an ancient Uighur or Early Turkic Runic. Finally, in 1972, the inscription was identified as Sogdian, but it remained out of the field of view of researchers for a long time. Almost 20 years later, in 1991 , a Japanese Sogdian scholar, Yutaka Yoshida, examined a photograph of the monument at the Xinjiang Institute of History and Archaeology and tried to read its text.

Both texts are very similar in paleographic features. In general, the Bugut inscription dedicated to Mahan Tekin, the brother and co-ruler of Muhan Kagan, and the inscription in memory of Niri Kagan show a high practical level of writing among the Sogdians on the routes of the Higher School of Economics far from their homeland, and are evidence of a high degree of literacy among them.

Let's start with the Bugut inscription. It occupies all four faces of the stele, measuring $1.98 \times 70 \times 20 \mathrm{~cm}$. The left side, front, and right sides of the stele are occupied by the Sogdian inscription, the lines of which are vertical, read from top to bottom, when they are taken from the left side. On the back of the stele is a poorly preserved text in the Brahmi script. The Sogdian text consisted of approximately 31-32 lines. The longest lines were about 110-120 cm. Due to the erosion of the sandstone and some fragments of the stele used for the inscription, the final and initial parts of some lines are lost. So, on 1-4 lines of text on the left side of the stele, from 10 to 30 letters are lost. About half of the entire length of the 1-8 lines of the front side of the inscription is captured by erosion and potholes. There are about 35 to 45 letters missing on these lines. On the damaged part, you can see barely discernible letters, rarely, individual words.

Almost one third of the 9-19 lines of the obverse are destroyed by a break in the upper right part of the stele. The text on the right side is also damaged by erosion to almost half of the first 4 lines. On the 5 th, last line, there are only faint traces of letters. 


\section{Sogdian Epitaphs in Honor Early Khagans of Tyurkik Khaganat}

The line spacing is mainly $5-5.5 \mathrm{~cm}$ with a letter height of about $1.5-2 \mathrm{~cm}$. A Sogdian (or Turk) carver, specially trained in language and writing, a professional, observed the spacing between lines and letters and the line spacing of lines. The skill of the carver is evident in the manner of using certain, perhaps his own favorite graphic variants of individual letters. In general, the Bugutkaya inscription is made in the Sogdian script of the initial cursive stage, which tends to be semi-cursive.

The Niri Kagan memorial inscription generally consists of about or more than 20 lines of semi-cursive Sogdian text. It is impossible to accurately set the number of lines due to the poor quality of the photo. Unfortunately, the situation was further complicated by the fact that the inscriptions were painted in the traces of natural lettering, which distorted many elements of the letters. This is especially evident from the 9 th line onwards.

The last lines on the left side of the monument are captured by erosion. Reading Y.The yoshida of the first 8 lines of the text is preliminary. So it does not define any letters on the first line. At the same time, there were no more than 30 letters on the line. However, you can see traces of the letters of one, more precisely, the second word from the beginning of this line, where the letters $\mathrm{m} / \mathrm{t}, \mathrm{w} / \mathrm{p}, \mathrm{y} / \mathrm{n}, \mathrm{s}, \mathrm{t}[\ldots]$ are distinguishable. This word can presumably be read as $\mathrm{t}(\mathrm{\prime}) \mathrm{p}(\mathrm{y}) \mathrm{nst}[\mathrm{n} \mathrm{n}$, while allowing for a complex word formation consisting of the Turkic base t'pin- "bow, reverance" and the Iranian top of ormant -st'n "place", that is, "place of bow\$ honour". Such an interpretation would be consistent with the designation of the memorial value of the monument.

At the beginning of the second line, Y.Yoshida reads the expression $c t \beta$ ' $r$ kyr'n $y r ß \ldots$ and leaves no comment. Judging by the parallels of the use of this expression in other, especially Sogdian texts of Buddhist content, it hints at the fact that the customers of the monument, and the Nivar Kagan himself, were already Buddhists. Meanwhile, in the Bugut inscription, as an important historical event, it is reported about the adoption of the religion of Buddhism in the khaganate during the reign of Muhan Khagan Next, the grammatical definition before the name Niri Kagan Y.Yoshida reads cwr p'y. As you know, the word cwr in Sogdian means "friendly, close", also a borrowing from the Turkic meaning friendly. This word in the Sogdian-Turkic society was considered as a title of the approximate supreme ruler. As for Niri Kagan, he could not bear the title of, as he was the first heir to the throne, being the grandson of Muhan Kagan. Based on this consideration, we suggest reading šyr instead of cwr. In such a reading, it would be šyr $\mathbf{p}^{\prime} \mathbf{y}^{1}$ nyry $\mathbf{x}^{\prime} \mathbf{y}^{\prime} \mathbf{n}$ "protecting with good, protecting (his people) Neary Kagan”.

Ashina Sheni in her electronic publication based on the reading of Y.Yoshida's word Byy in the text of the monument translates "divine".

For example, the phrase mwx'n x' $\boldsymbol{y}^{\prime} \mathbf{n}$ npyšn ßyy...nyry x' $\boldsymbol{y}^{\prime} \mathbf{n}$ translates as "grandson of Muhan Kagan the ruler...Neary Kagan" In this case, the word Byy should be understood as "lord" and not "divine".

\section{CONCLUSION}

Typologically close, these two monuments (Bugut stele and stele of Niri khagan) require further in-depth study. They most accurately reflect the history of the political life of the Great Turkic Khaganate in the first half-century of its existence.

It should be noted that before the appearance of the Bugut inscription and now - the inscription in memory of Niri Kagan, the original names of such Turkic kagans as Bumyn Kagan(died in 552), Muhan Kagan(553-572), Taspar Kagan (573-581), Nivar Kagan (581-587), Niri Kagan (587-599) who were previously known only in distorted Chinese phonetic forms.

\section{REFERENCES}

1) Klyashtorny S.G., Livshits V.A. Sogdian inscription from Bugut / Countries and peoples of the East. Issue X. M .: 1971. -S. 3-26.

2) Ashina Shani. Stele of Niri-Kagan. Sources on the history of Eurasia. Forum of the Eurasian Historical Server. August 12, 2017 -S.1-7a.

3) Ashina Shani. Stele of Niri-Kagan. Sources on the history of Eurasia. Forum of the Eurasian Historical Server. August 12, $2017-$-C.7.

4) Iskhakov M.M. Central Asia in the system of world written culture (antiquity and early Middle Ages). Tashkent: RIO UWED, 2008. - S. 112-113.

5) Livshits V.A. Sogdian epigraphy of Central Asia and Semirechye. Research. St. Petersburg State University, Faculty of Philology. SPb. 2008 .-- 210 p.

6) Ibid. - P.29. See also Iskogov M. Unutilgan podsholikdan khatlar. Toshkent. Fan, 1992.-B.12-13.

7) Sogdian documents from Mount Mug. Legal documents and letters. Reading, translation and comments by V.A. Livshits. $M .: 1962 .--242 p$.

8) Ibid. - P.29. See also: Iskogov M. Unutilgan podsholikdan khatlar. Toshkent. Fan, 1992.-B.12-13. 